\title{
Anaphylaxis to Vespa velutina nigrithorax: Pattern of Sensitization for an Emerging Problem in Western Countries
}

\author{
Vidal $\mathrm{C}^{1,2}$, Armisén $\mathrm{M}^{1}$, Monsalve $\mathrm{R}^{3}$, González-Vidal $\mathrm{T}^{1}$, Lojo $\mathrm{S}^{4}$, López-Freire $\mathrm{S}^{1}$, Méndez $\mathrm{P}^{1}$, \\ Rodríguez $\mathrm{V}^{1}$, Romero L', Galán $\mathrm{A}^{3}$, González-Quintela $\mathrm{A}^{2,5}$ \\ 'Allergy Department, Complejo Hospitalario Universitario de Santiago, School of Medicine, University of Santiago de Compostela, Spain
2Spanish Network for Addictive Disorders (Red de Trastornos Adictivos, RD16/0017/0018), Spain
3CMC R\&D (Chemistry, Manufacturing and Control Research and Development), ALK-Abello, Madrid, Spain
'Department of Biochemistry, Complejo Hospitalario Universitario de Santiago, Santiago de Compostela, Spain
${ }^{4}$ Department of Medicine, Complejo Hospitalario Universitario de Santiago, Faculty of Medicine, University of Santiago de Compostela, Spain
}

J Investig Allergol Clin Immunol 2021; Vol. 31(3): 228-235

doi: 10.18176/jiaci.0474

\begin{abstract}
Objective: To define the sensitization pattern of patients with anaphylaxis to Vespa velutina nigrithorax (VVN).

Methods: We studied 100 consecutive Spanish patients with anaphylaxis to Hymenoptera venom and systematically determined specific $\lg \mathrm{E}(\mathrm{s} \lg \mathrm{E})$ to whole venoms (Vespula species, Polistes dominula, Apis mellifera, Vespa crabro, and Dolichovespula maculata) and their molecular components (rApi m 1, rApi m 5, rApi m 10, rVes v 1, rVes v 5, rPol d 5, and cross-reactive carbohydrates). Specific lgE to VVN venom and its antigen 5 (nVesp v 5) were measured in a subsample.

Results: Seventy-seven patients had anaphylaxis to VVN. Of these, only $16(20.8 \%)$ reported previous VVN stings, but were stung by other Hymenoptera. Positive slgE $\left(>0.35 \mathrm{kU}_{\mathrm{A}} / \mathrm{L}\right)$ to each of the whole venoms was detected in $>70 \%$ of patients (Vespula species in $\left.100 \%\right)$. The components showing $>50 \%$ positivity were rApi $m 5(51.4 \%)$, rPol d $5(80.0 \%)$, and rVes $\vee 5(98.7 \%)$. This pattern was similar to that of Vespula species anaphylaxis $(n=11)$ but different from that of $A$ mellifera anaphylaxis $(n=10)$. Specific lgE to $n V e s p \vee 5$ was positive in all patients $(n=15)$ with VVN anaphylaxis and was correlated with slgE to both rVes $\vee 5(R=0.931)$ and $r P o l d ~ 5(R=0.887)$.

Conclusions: VVN has become the commonest cause of Hymenoptera anaphylaxis in our area. Most cases report no previous VVN stings. Their sensitization pattern is similar to that of patients with anaphylaxis to other Vespidae. Specific lgE to antigen-5 from VVN, Vespula species, and $P$ dominula are strongly correlated in patients with VVN anaphylaxis.
\end{abstract}

Key words: Vespa velutina nigrithorax. Anaphylaxis. Ves v 5. Pol d 5. Vesp v 5. Allergy. Hymenoptera.

\section{Resumen}

Objetivo: Definir el patrón de sensibilización alérgica de pacientes con anafilaxia por Vespa velutina nigrithorax (VVN), un problema emergente en países occidentales.

Métodos: Se estudió una población de 100 pacientes adultos con anafilaxia por veneno de himenóptero en España. Se determinó IgE específica frente a los venenos completos de Vespula spp, Polistes dominula, Apis mellifera, Vespa crabro, Dolichovespula maculata, y algunos de sus componentes moleculares (rApi m 1, rApi m 5, rApi m 10, rVes v 1, rVes v 5, rPol d 5, carbohidratos [MUXF]). En una muestra de 15 pacientes con anafilaxia por VVN se determinó la IgE específica frente a este veneno completo y al antígeno 5 de VVN (denominado nVesp v 5).

Resultados: Setenta y siete pacientes (77,0\%) padecieron anafilaxia por VVN. De ellos, tan solo 16 (20,8\%) habían padecido picaduras previas por VVN si bien reconocían picaduras previas por otros himenópteros. Más del $70 \%$ de los pacientes con anafilaxia por VVN presentaron IgE específica positiva $\left(>0,35 \mathrm{kU}_{\mathrm{A}} / \mathrm{L}\right.$ ) frente a cada uno de los venenos completos estudiados (el $100 \%$ en el caso de Vespula spp). Los componentes moleculares reconocidos por la lgE de más del $50 \%$ de los pacientes fueron rApi m 5 (51,4\%), rPol d 5 (80,0\%), y rVes v $5(98,7 \%)$. Este patrón de sensibilización fue similar al de los pacientes con anafilaxia por Vespula spp $(n=11)$ y diferente al de los pacientes con anafilaxia por Apis mellifera $(n=10)$. La IgE específica frente a nVesp v 5 fue positiva en el $100 \%$ de los pacientes con anafilaxia por VVN analizados (15/15). La correlación entre la IgE específica frente a nVesp v 5 y la IgE específica frente a rVes $\vee 5$ $(R=0,931)$ y $r$ Pol d $5(R=0,887)$ fue muy significativa.

Conclusiones: VVN es la principal especie de himenóptero responsable de anafilaxia en la actualidad en nuestra área. El perfil de sensibilización es similar al de los pacientes con anafilaxia por otros Véspidos. La lgE específica frente al antígeno 5 de VVN, Vespula spp, y Polistes dominula se correlaciona estrechamente en los pacientes con anafilaxia por VVN.

Palabras clave: Vespa velutina nigrithorax. Anafilaxia. Ves v 5. Pol d 5. Vesp v 5. Alergia. Hymenoptera. 


\section{Introduction}

Alien species causing biological invasions are recognized as a significant problem nowadays, primarily because of the impact on biodiversity, but also because they cause new health problems. Vespa velutina nigrithorax (VVN), commonly known in Spain as Asian wasp, is one of the 12 color variants of Vespa velutina Lepeletier 1836, which is naturally distributed in Asia from Afghanistan to eastern China, Indochina, and Indonesia [1]. The first record of the presence of VVN in Europe was in 2005 in Lot-et-Garonne, France, where it was thought to have arrived in 2004 [2]. This unexpected invasion seems to have been due to an accidental transport of at least 1 hibernating founder queen in pottery or other horticultural commercial products from China (bonsai tree) [3,4]. From that moment onwards, VVN has spread rapidly across France [5-7] and the Basque Country in the North of Spain [8]. In 2011, Villemant et al [7] published an interesting model predicting the future invasion of VVN. The model predicted that many countries in western Europe had a high probability of being invaded, with the highest risk being along the Atlantic and northern Mediterranean coasts. Coastal areas of the Balkan Peninsula, Turkey, and Near East also appeared suitable and could potentially be colonized later [7]. Other parts of the world with high climatic suitability for this species could also be threatened by VVN, since the species could enter again through international trade [7]. This prediction is now a reality, since VVN has spread into Spain (particularly in the north and northwestern areas (information available at http://webs-gis. cesga.es/velutina/), Portugal, Italy, and the UK $[4,9,10]$. In Galicia, a region in the northwest of Spain, more than 47394 nests were identified and 24196 retrieved and destroyed in 2018 (compared to 769 in 2014) (Consellería de Medio Rural, Xunta de Galicia).

Vespa velutina is one of the most aggressive and feared Hymenoptera species in China, where it is known as killer wasp, because it causes a number of deaths every year [11]. Most affected persons die after multiple stings because of multiple organ dysfunction induced by toxins in the venom [11,12]. Apart from these toxic effects, $V$ velutina can provoke allergic reactions similar to those caused by other Hymenoptera species. In fact, up to 6 deaths after VVN stings, presumably due to fatal allergic reactions, were reported by the media in Spain in 2017 and 2018 ( 5 in the northwest). For that reason, the population of the north and northwest of Spain has been alerted to the presence of VVN, and specific political campaigns have been activated to fight against the invasion. The first well-identified case of anaphylaxis due to VVN in Spain was reported in 2014 [13]. The first patient with anaphylaxis to VVN in our area was detected in June 2015. Two additional cases were seen in 2016 and 9 in 2017. This increase in the frequency of anaphylaxis to VVN and the lack of commercially available assays for identifying specific IgE (sIgE) against VVN or its components led us to initiate the present study. Our objective was to identify the sensitization profile of patients with anaphylaxis to VVN and to compare it with that of patients who experience anaphylaxis caused by other Hymenoptera. We used commercially available sIgE determinations against both the whole venom and molecular components of Vespula species, Polistes dominula, Apis mellifera, Vespa crabro, and Dolichovespula maculata. We also aimed to investigate the usefulness of a customized test to detect
VVN-sIgE based on binding biotin to the whole venom extract and to its purified components, phospholipase and antigen 5 (namely Vesp v 1 and Vesp v 5).

\section{Patients and Methods}

\section{Study Population and Design}

We performed a cross-sectional study in which we prospectively enrolled all adult individuals with anaphylaxis due to Hymenoptera venom who attended our Allergy Department for the first time between December 2017 and June 2019. Our institution is a reference teaching hospital in northwest Spain. Patients were submitted from either primary care or the emergency department after experiencing an anaphylactic reaction to Hymenoptera sting. Patients with large local reactions were not included in the study. The hospital covers an area of approximately 500000 people, of whom nearly 90000 live in the city of Santiago de Compostela and the remainder in primarily rural areas. All eligible patients $(n=100)$ agreed to participate. The median age was 63 years (range, 20 90 years), and 87 (87.0\%) were males. Most patients (97 [97\%]) lived in a rural environment, and 57 (57\%) worked outdoors, thus leading them to be considered at high risk of exposure.

A physician-administered structured questionnaire was completed for every patient to obtain a series of data: (a) identification of the Hymenoptera species involved in the reaction (bees, common wasps, and VVN); (b) recall of previous Hymenoptera stings (bees, common wasps, and VVN); (c) a history of previous systemic reactions after Hymenoptera stings; $(d)$ time elapsed between exposure to Hymenoptera venom and when symptoms and appearance of the first signs; (e) signs and symptoms reported by the patient; $(f)$ signs and symptoms reported by doctors who treated the patients after the reaction; and $(g)$ history of Hymenoptera stings after the reported reaction and before entering the study. The severity of the systemic reaction was classified based on the information recorded and divided into 3 categories: mild (skin and subcutaneous lesions plus nonspecific general symptoms), moderate (features suggesting respiratory, cardiovascular, or gastrointestinal involvement), and severe (hypoxia, hypotension, or neurologic compromise) (adapted from [14]), as accepted for systemic reactions to Hymenoptera venom [15]. Information was recorded between 15 and 30 days after the reaction and all laboratory determinations were performed in serum samples obtained under baseline conditions 1-2 months after the reaction. Finally, and following the recommendations of the European Competence Network on Mastocytosis, we recorded the Spanish Mastocytosis Network (REMA) score [16] to calculate the risk of a clonal mast cell disorder that could increase the severity of the reaction.

\section{Laboratory Determinations}

\section{Commercially available specific IgE}

Allergen sIgE was measured using the ImmunoCAP-250 system (Thermo Fisher Scientific) and included sIgE against Vespula species, Pdominula, A mellifera, V crabro, D maculata, rApi m 1, rApi m 5, rApi m 10, rVes v 1, rVes v 5, rPol d 5, and MUXF (o214) as a marker of cross-reactive carbohydrate 
determinant (CCD). Following the manufacturer's instructions, sIgE levels $\geq 0.1 \mathrm{kU}_{\mathrm{A}} / \mathrm{L}$ were deemed positive, although analyses were performed with the classic $0.35-\mathrm{kU}_{\mathrm{A}} / \mathrm{L}$ threshold level for positivity.

\section{Customized specific IgE}

We measured sIgE to VVN whole venom extract and to VVN phospholipase and antigen 5 (nVesp v 1 and nVesp v 5, respectively) in a subsample of 15 patients with anaphylaxis to VVN. The nVesp v 1 and 5 components were purified from an extract of VVN venom (ALK-Source Materials) by successive chromatographic steps [17] in a procedure similar to that used for purifying the allergenic components of Vespula species and $P$ dominula [18]. VVN whole venom extract and nVesp v 1 and nVesp v 5 proteins were biotinylated [19], bound to highstreptavidin-coated high-capacity plates (o212, Thermo Fisher Scientific, Inc.), and subsequently used as specific reagents in the ImmunoCAP-250 platform.

\section{Serum total IgE}

Total IgE was measured in serum samples using a chemiluminescence immunoassay in a Centaur XP System analyzer (Siemens).

\section{Serum tryptase}

Serum tryptase was determined using the ImmunoCAP 250 tryptase assay (Thermo Fisher Scientific).

\section{Statistical Analyses}

The chi-square test (with continuity correction and analysis of trend, when needed) was used to compare proportions. The Mann-Whitney test was used to compare numerical variables between groups. The Jonckheere-Terpstra test was used to analyze the trend of numerical variables in relation to ordinal categories. The Pearson test was used to assess correlation. Linear regression was used to predict the value of a dependent variable (VVN-sIgE) based upon the values of independent variables (commercially available sIgE to related allergens).

\section{Ethics}

The study was approved by the Institutional Ethics Committee and complied with the recommendations of the Declaration of Helsinki. Written informed consent was obtained from all participants.

Table 1. Clinical Data of Study Patients Stratified by Culprit Insect

\begin{tabular}{|c|c|c|c|c|c|}
\hline & \multicolumn{3}{|c|}{ Culprit Insect } & \multicolumn{2}{|c|}{$P$ Value $^{\mathrm{a}}$} \\
\hline & $\begin{array}{l}\text { Vespula species } \\
\qquad(\mathrm{n}=11)\end{array}$ & $\begin{array}{l}\text { Vespa velutina } \\
\text { nigrithorax }(\mathrm{n}=77)\end{array}$ & $\begin{array}{l}\text { Apis mellifera } \\
\quad(\mathrm{n}=10)\end{array}$ & $\begin{array}{l}\text { VVN vs } \\
\text { VV }\end{array}$ & $\begin{array}{l}\text { VVN vs } \\
\text { AM }\end{array}$ \\
\hline Age, $\mathrm{y}^{\mathrm{b}}$ & $58(56-65)$ & $63(54-69)$ & $54(41-68)$ & .618 & .348 \\
\hline Male sex & $11(100)$ & $66(85.7)$ & $9(90.0)$ & .394 & .712 \\
\hline $\begin{array}{l}\text { History of previous stings } \\
\text { Vespula species } \\
\text { Vespa velutina nigrithorax } \\
\text { Apis mellifera }\end{array}$ & $\begin{array}{l}11(100) \\
2(18.2) \\
6(54.5)\end{array}$ & $\begin{array}{l}75(97.4) \\
16(20.8) \\
41(53.2)\end{array}$ & $\begin{array}{c}8(80.0) \\
0(0.0) \\
10(100)\end{array}$ & $\begin{array}{l}.999 \\
.999 \\
.936\end{array}$ & $\begin{array}{l}.095 \\
.245 \\
.013\end{array}$ \\
\hline $\begin{array}{l}\text { Previous systemic reactions } \\
\text { Vespula species } \\
\text { Vespa velutina nigrithorax } \\
\text { Apis mellifera }\end{array}$ & $\begin{array}{l}1(9.1) \\
0(0.0) \\
0(0.0)\end{array}$ & $\begin{array}{l}13(16.9) \\
5(6.5) \\
0(0.0)\end{array}$ & $\begin{array}{c}0(0.0) \\
0(0.0) \\
3(30.0)\end{array}$ & $\begin{array}{l}.826 \\
.862 \\
.999\end{array}$ & $\begin{array}{r}.349 \\
.914 \\
<.001\end{array}$ \\
\hline Habitat (rural) & $11(100)$ & $75(97.4)$ & $9(90.0)$ & .999 & .775 \\
\hline Occupational exposure (outdoors) & $8(72.7)$ & $43(55.8)$ & $5(50.0)$ & .463 & .991 \\
\hline $\begin{array}{l}\text { Grade of anaphylaxis } \\
\text { Grade I } \\
\text { Grade II } \\
\text { Grade III }\end{array}$ & $\begin{array}{l}3(27.3) \\
4(36.4) \\
4(36.4)\end{array}$ & $\begin{array}{l}12(15.6) \\
33(42.9) \\
32(41.6)\end{array}$ & $\begin{array}{l}2(20.0) \\
6(60.0) \\
2(20.0)\end{array}$ & .628 & .419 \\
\hline $\begin{array}{l}\text { Time to reaction } \\
\text { Less than } 15 \text { min } \\
15-30 \text { min } \\
\text { More than } 30 \mathrm{~min}\end{array}$ & $\begin{array}{c}7(63.6) \\
3(27.3) \\
1(9.1)\end{array}$ & $\begin{array}{c}61(79.2) \\
12(15.6) \\
4(5.2)\end{array}$ & $\begin{array}{c}7(70.0) \\
3(30.0) \\
0(0.0)\end{array}$ & .514 & .431 \\
\hline Use of adrenaline & $5(45.5)$ & $37(48.1)$ & $5(50.0)$ & .872 & .908 \\
\hline
\end{tabular}

aVVN vs VV, comparison of Vespa velutina nigrithorax with Vespula species.

VVN vs AM, comparison of Vespa velutina nigrithorax with Apis mellifera.

${ }^{b}$ Age data are median and interquartile range (in parenthesis). The remainder are absolute numbers and percentages (in parenthesis). 


\section{Results}

\section{Clinical Data}

Seventy-seven patients $(77.0 \%)$ identified VVN as the insect responsible for the reaction. Only $11(11.0 \%)$ and 10 (10.0\%) patients identified the common wasp (Vespula species) and honeybee (A mellifera) as the culprit insect, respectively. Two patients $(2 \%)$ did not recognize the insect involved in the reaction.

All patients with anaphylaxis to Vespula species and $A$ mellifera reported previous stings by the culprit insect. In contrast, only $20.8 \%(16 / 77)$ of patients with anaphylaxis to VVN reported a previous sting by this species. However, all patients with anaphylaxis to VVN reported previous stings by either Vespula species $(75 / 77,97.4 \%)$ or A mellifera $(41 / 77$, $53.2 \%)$. Twenty-three patients reported past episodes of anaphylaxis before the present attack, even though they had not been sent for evaluation (14 episodes related to Vespula species, 5 to $\mathrm{VVN}$, and 4 to $A$ mellifera). No additional stings were recorded after the last systemic reaction and before inclusion in the study. No differences were found regarding the culprit insect with respect to age, sex, environment (rural or urban), or occupation (outdoors or indoors) (Table 1).

Most reactions happened in the first 15 minutes after the sting, with no differences regarding the culprit insect (Table 1). The anaphylactic reaction was mild in 17 cases $(17 \%)$, moderate in $45(45 \%)$, and severe in $38(38 \%)$ cases. Severity of anaphylaxis to VVN was similar to that of anaphylaxis to Vespula species or A mellifera (Table 1). Adrenaline was used in 48 patients $(48 \%)$ : the more severe the reaction, the more frequent the use of adrenaline $(17.6 \%$ in mild reactions, $44.4 \%$ in moderate reactions, and $65.8 \%$ in severe reactions;
$P<.001$, trend test). Baseline serum tryptase levels (available for all patients) tended to increase with the severity of the anaphylactic reaction. Median tryptase was $3.9 \mathrm{ng} / \mathrm{mL}$ (3.6$5.4 \mathrm{ng} / \mathrm{mL}), 4.5 \mathrm{ng} / \mathrm{mL}(3.5-5.9 \mathrm{ng} / \mathrm{mL})$, and $5.4 \mathrm{ng} / \mathrm{mL}$ (4.3-6.7 ng/mL), in patients with mild, moderate, and severe reactions, respectively $(P=0.015$, trend test). However, serum tryptase levels were similar in patients with anaphylaxis to VVN, Vespula species, and A mellifera (Table 2). The REMA score was $<2$ in 98 patients. Only 2 patients, both of whom belonged to the VVN group, had a REMA score higher than 2 , although the hematological study performed enabled us to rule out the presence of a clonal mast cell disorder.

\section{Sensitization Profile}

\section{Commercially available specific IgE determinations}

Specific IgE against Vespula species was available in 76/77 patients with anaphylaxis to $\mathrm{VVN}$, and results were positive $\left(>0.35 \mathrm{kU}_{\mathrm{A}} / \mathrm{L}\right)$ for all of them. Most patients with anaphylaxis to $\mathrm{VVN}(70 \%)$ also had positive $\mathrm{sIgE}$ to the whole venom extract of $D$ maculata, $P$ dominula, V crabro, and A mellifera, in that order (Figure 1). Regarding molecular components, patients with anaphylaxis to VVN had positive sIgE to Vespula species rVes v 5 more frequently than to rVes v 1 . Specific IgE to $P$ dominula $\mathrm{rPol} \mathrm{d} 5$ was present in most patients with anaphylaxis to VVN. The only molecular component from A mellifera with a positive sIgE rate $>50 \%$ in patients with anaphylaxis to VVN was rApi m 5 (Figure 1).

Patients with anaphylaxis due to VVN had similar levels of sIgE against Vespula species, $P$ dominula, rVes v1, rVes v 5, rPol d 5, D maculata, and $V$ crabro than patients with anaphylaxis due to Vespula species. In contrast, patients

Table 2. Laboratory Data for Study Patients Stratified by Culprit Insect

\begin{tabular}{|c|c|c|c|c|c|c|c|c|}
\hline & \multicolumn{6}{|c|}{ Culprit Insect } & \multicolumn{2}{|c|}{$P$ Value $^{\mathrm{a}}$} \\
\hline & \multicolumn{2}{|r|}{$\begin{array}{l}\text { Vespula } \\
\text { species }\end{array}$} & \multicolumn{2}{|r|}{$\begin{array}{l}\text { Vespa velutina } \\
\text { nigrithorax }\end{array}$} & \multicolumn{2}{|r|}{$\begin{array}{c}\text { Apis } \\
\text { mellifera }\end{array}$} & \multirow[b]{2}{*}{ VVN vs VV } & \multirow[b]{2}{*}{ VVN vs AM } \\
\hline & $\mathrm{n}$ & Median (IQR) & $\mathrm{n}$ & Median (IQR) & $\mathrm{n}$ & Median (IQR) & & \\
\hline \multicolumn{9}{|l|}{ Serum specific $\operatorname{IgE}, \mathrm{kU}_{\mathrm{A}} / \mathrm{L}$} \\
\hline MUXF & 11 & $0.20(0.00-0.92)$ & 77 & $0.05(0.00-0.34)$ & 10 & $0.09(0.00-1.55)$ & .362 & .562 \\
\hline Apis mellifera & 11 & $1.12(0.31-3.79)$ & 76 & $0.91(0.22-3.67)$ & 10 & $7.48(2.88-27.4)$ & .655 & $<.001$ \\
\hline rApi m 1 & 10 & $0.07(0.00-0.35)$ & 76 & $0.01(0.00-0.12)$ & 10 & $2.45(1.50-7.79)$ & .332 & $<.001$ \\
\hline rApi m 5 & 10 & $1.17(0.11-10.2)$ & 72 & $0.50(0.00-3.93)$ & 9 & $1.15(0.02-15.4)$ & .432 & .710 \\
\hline rApi m 10 & 10 & $0.04(0.01-0.07)$ & 75 & $0.03(0.00-0.86)$ & 10 & $0.31(0.04-2.25)$ & .802 & .053 \\
\hline Vespula species & 11 & $14.0(8.51-57.3)$ & 76 & $5.38(2.03-14.2)$ & 9 & $0.08(0.00-7.23)$ & .019 & .007 \\
\hline rVes v 1 & 11 & $0.07(0.03-5.98)$ & 77 & $0.15(0.03-1.44)$ & 9 & $0.00(0.00-1.29)$ & .870 & .820 \\
\hline rVes v 5 & 11 & $12.4(0.52-65.0)$ & 76 & $4.45(1.48-12.3)$ & 9 & $0.00(0.00-0.75)$ & .322 & $<.001$ \\
\hline Polistes dominula & 11 & $4.22(2.95-36.1)$ & 77 & $1.54(0.41-6.72)$ & 9 & $0.06(0.00-2.43)$ & .060 & .024 \\
\hline rPol d 5 & 11 & $6.89(0.85-15.7)$ & 75 & $1.65(0.50-8.31)$ & 9 & $0.01(0.00-0.57)$ & .151 & .001 \\
\hline Dolichovespula $m$ & 7 & $4.78(1.10-13.5)$ & 76 & $1.34(0.42-4.05)$ & 8 & $0.15(0.00-8.85)$ & .046 & .185 \\
\hline Vespa crabro & 7 & $2.98(0.98-3.79)$ & 75 & $0.93(0.34-3.34)$ & 9 & $0.02(0.00-8.48)$ & .137 & .073 \\
\hline Serum total $\operatorname{IgE}, \mathrm{kU} / \mathrm{L}$ & 11 & $189(126-264)$ & 76 & $78.5(33.0-198)$ & 10 & $45.0(16.2-182)$ & .017 & .247 \\
\hline Serum tryptase, $\mathrm{ng} / \mathrm{mL}$ & 11 & $4.3(3.5-5.2)$ & 77 & $5.1(3.9-6.4)$ & 10 & $4.5(4.1-6.3)$ & .304 & .868 \\
\hline
\end{tabular}

Abbreviations: MUXF (0214), marker of cross-reactive carbohydrate determinant; Dolichovespula m, Dolichovespula maculata. aVVN vs VV, comparison of Vespa velutina nigrithorax with Vespula species.

VVN vs AM, comparison of Vespa velutina nigrithorax with Apis mellifera. 


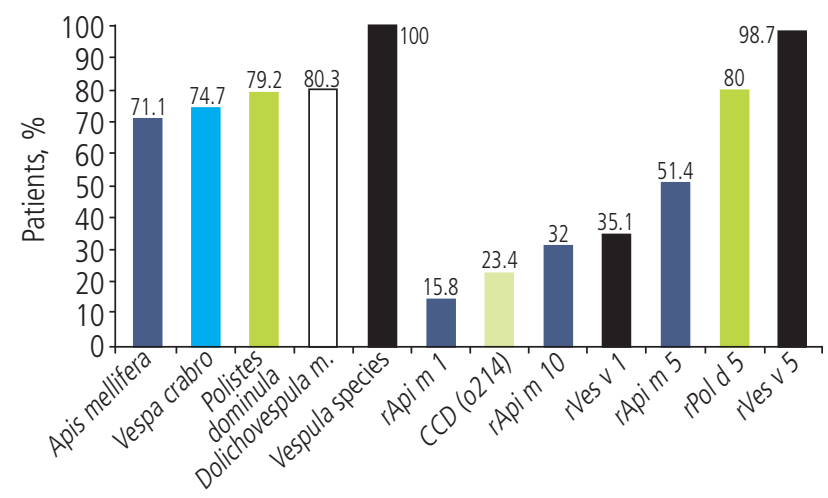

Figure 1. Percentage of patients with anaphylaxis due to Vespa velutina nigrithorax and positive slgE $(>0.35 \mathrm{kUA} / \mathrm{L})$ to whole Hymenoptera venoms (Vespula species [ $n=76]$, Polistes dominula [ $n=77]$, Apis mellifera [n=76], Vespa crabro [n=75], and Dolichovespula maculata [ $n=76]$, left side) and their molecular components (rApi m 1 [n=76], rApi m 5 [ $n=72]$, rApi m $10[n=75]$, rVes v $1[n=77]$, rVes v $5[n=76]$, rPol d 5 [n=75], and 0214 [MUXF, as a CCD marker, $\mathrm{n}=77$ ], right side). Each venom and its molecular components are represented with the same color to facilitate identification.

with anaphylaxis to VVN had lower levels of sIgE against A mellifera and its main allergen, rApi $\mathrm{m} 1$, than patients with anaphylaxis to A mellifera. Of note, sIgE levels to rApi $\mathrm{m}$ 5, rApi m 10, rVes v 1, and the CCD marker (MUXF, o214) were similar in all patients, irrespective of the culprit insect (Table 2).

Patients with anaphylaxis to Vespula species presented higher levels of total IgE than patients with anaphylaxis to VVN or A mellifera (Table 2). A similar profile was observed when concentrations of venom-specific IgE were considered in relation to total IgE, ie, patients with anaphylaxis to VVN displayed a pattern of sIgE sensitization similar to that of patients with anaphylaxis to Vespula species and different from that of patients with anaphylaxis to A mellifera (Table 3).

\section{Customized specific IgE determinations}

In a subsample of 15 patients with anaphylaxis to $\mathrm{VVN}$, $13(86.6 \%)$ had positive $\operatorname{sigE}\left(>0.35 \mathrm{kU}_{\mathrm{A}} / \mathrm{L}\right)$ to a whole
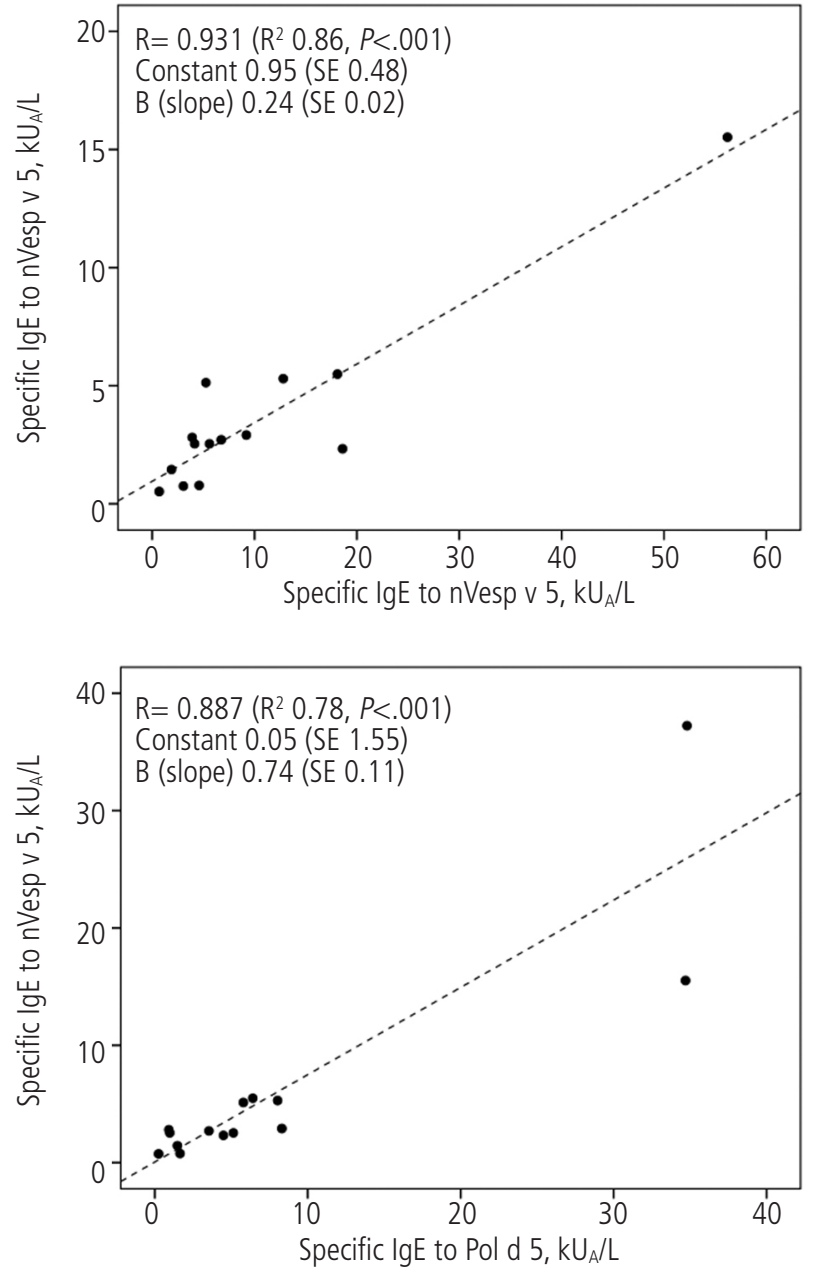

Figure 2. Scatterplots representing the relationship between serum specific lgE to rVes $v 5$ and rPol d 5 and specific IgE to Vespa velutina nigrithorax antigen 5 (nVesp v 5). Linear regression models were constructed to predict nVesp $\vee 5$ concentrations as a function of rVes $\vee 5$ and rPol d 5 concentrations, thus explaining $86 \%$ and $78 \%$ of the variability of $n V e s p \vee 5$, respectively.

Table 3. Ratio of Serum Specific lgE to Serum Total IgE for Study Patients Stratified by Culprit Insect

\begin{tabular}{|c|c|c|c|c|c|c|c|c|}
\hline \multirow[b]{3}{*}{$\begin{array}{l}\text { Ratio of serum specific IgE, } \\
\mathrm{kU}_{\mathrm{A}} / \mathrm{L} \text { to total IgE, } \mathrm{kU} / \mathrm{L}(\times 100)\end{array}$} & \multicolumn{6}{|c|}{ Culprit Insect } & \multicolumn{2}{|c|}{$P$ Value $^{\mathrm{a}}$} \\
\hline & \multicolumn{2}{|r|}{$\begin{array}{l}\text { Vespula } \\
\text { species }\end{array}$} & \multicolumn{2}{|r|}{$\begin{array}{l}\text { Vespa velutina } \\
\text { nigrithorax }\end{array}$} & \multicolumn{2}{|r|}{$\begin{array}{l}\text { Apis } \\
\text { mellifera }\end{array}$} & \multirow[b]{2}{*}{$\begin{array}{l}\text { VVN vs } \\
\text { VV }\end{array}$} & \multirow[b]{2}{*}{$\begin{array}{l}\text { VVN vs } \\
\text { AM }\end{array}$} \\
\hline & $\mathrm{n}$ & Median (IQR) & $\mathrm{n}$ & Median (IQR) & $\mathrm{n}$ & Median (IQR) & & \\
\hline Apis mellifera & 11 & $0.51(0.34-1.43)$ & 76 & $1.07(0.31-2.92)$ & 10 & $16.7(12.3-38.3)$ & .358 & $<.001$ \\
\hline Vespula species & 11 & $8.45(5.93-21.0)$ & 75 & $5.54(3.12-15.7)$ & 9 & $0.22(0.0-1.64)$ & .419 & $<.001$ \\
\hline Polistes dominula & 11 & $3.27(1.01-13.8)$ & 76 & $2.02(0.84-5.63)$ & 9 & $0.18(0.0-4.16)$ & .319 & .040 \\
\hline Vespa crabro & 7 & $1.12(0.58-3.46)$ & 74 & $1.91(0.59-3.35)$ & 9 & $0.11(0.0-1.81)$ & .814 & .043 \\
\hline Dolichovespula maculata & 7 & $1.83(1.25-7.11)$ & 75 & $1.97(0.85-3.35)$ & 8 & $0.83(0.0-2.52)$ & .578 & .112 \\
\hline
\end{tabular}

aVN vs VV, comparison of Vespa velutina nigrithorax with Vespula species.

VVN vs AM, comparison of Vespa velutina nigrithorax with Apis mellifera. 
venom extract of VVN. Levels of SIgE to VVN were low (median [IQR], $1.1 \mathrm{kU}_{\mathrm{A}} / \mathrm{L}$ [0.12-20.5 $\left.\mathrm{kU}_{\mathrm{A}} / \mathrm{L}\right]$ ). Using the same methodology, $100 \%$ of these patients presented positive sIgE to nVesp v 5, while only $28.8 \%$ presented positive sIgE levels to $n V e s p ~ v 1$. Median (IQR) levels of sIgE to nVesp $v 5$ (2.71 [0.52-37.2 $\left.\left.\mathrm{kU}_{\mathrm{A}} / \mathrm{L}\right], \mathrm{n}=15\right)$ tended to be higher than those of sIgE to nVesp v $1\left(0.17 \mathrm{kU}_{\mathrm{A}} / \mathrm{L},\left[0.99-27.1 \mathrm{kU}_{\mathrm{A}} / \mathrm{L}\right], \mathrm{n}=14\right)$ and tended to be higher than those of $\operatorname{sIgE}$ to whole venom extract of VVN (2.71 [0.52-37.2 kU $\left.\left.\mathrm{k}_{\mathrm{A}} / \mathrm{L}\right], \mathrm{n}=15\right)$. A significant correlation was found between SIgE to VVN and SIgE to Vespula species $(\mathrm{R}=0.669, P=.009), P$ dominula $(\mathrm{R}=0.620$, $P=.014), D$ maculata $(\mathrm{R}=0.973, P<.001)$, and $V$ crabro $(\mathrm{R}=0.968, P<.001)$. There was also a strong correlation between sIgE to nVesp v 5 and sIgE to rVes v $5(\mathrm{R}=0.931$, $P<.001)$ and between sIgE to $n$ Vesp v 5 and $\mathrm{rPol} d 5(\mathrm{R}=0.887$, $P<.001)$. Figure 2 shows a scatterplot of nVesp v 5 in relation to rVes $v 5$ and $\mathrm{rPol} \mathrm{d} 5$ and linear regression parameters to predict the level of sIgE to $n V e s p$ v5, given the values of rVes $v 5$ and rPol d 5. Finally, no significant correlation was found between sIgE to nVesp v 1 and sIgE to rVes v 5 and rVes v $1(\mathrm{R}=0.429$, $P=.143, \mathrm{R}=0.002, P=.993)$.

\section{Discussion}

The present study enables us to conclude the following: (a) Anaphylaxis to VVN has increased rapidly in frequency recent years in our area, where it represents the most common form of Hymenoptera anaphylaxis today; (b) Most patients with anaphylaxis to VVN do not report previous stings by VVN, although they do report previous stings to other Hymenoptera, especially common wasps (Vespula species); (c) The IgE sensitization profile of patients with anaphylaxis to VVN is similar to that of patients with anaphylaxis to other Vespidae; and (d) Most patients with VVN anaphylaxis show sIgE to antigen 5 from Vespula species (rVes v 5) and antigen 5 from $P$ dominula ( $\mathrm{rPol} \mathrm{d} \mathrm{5),} \mathrm{which} \mathrm{is} \mathrm{strongly} \mathrm{correlated}$ with sIgE to antigen 5 from VVN (n Vesp v 5) in the same patients. Taken together, these findings suggest a degree of cross-reactivity between VVN and other Vespidae, which may be important for sensitization and relevant for diagnostic and therapeutic purposes.

Our data confirm anaphylaxis to VVN to be a significant emerging problem. The number of patients reporting anaphylaxis to VVN has increased exponentially from the first case in 2015 in our area. The number of incident cases of anaphylaxis caused by other Hymenoptera remained stable in those years, although more than three-quarters of incoming patients reporting Hymenoptera anaphylaxis today identify VVN as the culprit insect. As an example, and considering the number of patients receiving venom immunotherapy, while $60.3 \%$ of 126 patients were being treated with $A$ mellifera venom in $2015,68.2 \%$ of 245 were being treated with Vespula species venom in June 2019 (most after experiencing anaphylaxis to VVN). To the best of our knowledge, this is the largest series of VVN anaphylaxis that has been reported in the English-language literature. The paucity of previous reports is noteworthy. We found no scientific reports of anaphylaxis to VVN or anaphylaxis to V velutina variants from the countries of origin in Asia. In the case of European countries where VVN has expanded, we found only 1 case of VVN anaphylaxis in the literature, corresponding to the first case described in 2014 in Spain [13]. While cases of VVN anaphylaxis are commonly reported by the mass media in Spain, underreporting of epidemiological, clinical, and immunological characteristics of VVN anaphylaxis prompted us to report this series in an attempt to fill the knowledge gap for this emerging, relevant clinical problem.

Importantly, most of the patients who experienced anaphylaxis to VVN did not recall previous stings from the insect. This fact, together with the results of $\operatorname{sigE}$ determinations, supports the idea that, in our study, allergic reactions to VVN may develop after stings by other Hymenoptera, mainly Vespula species. It could also explain why patients reported here more frequently reacted against Vespula species than against V crabro, which is nearer to VVN than Vespula species. Likewise, cases of anaphylaxis to Vespa orientalis (a different member of the Vespidae family) without previous stings by this insect were reported in American soldiers deployed in Afghanistan [20]. The existence of crossreactivity among allergens from different Vespidae could explain these reactions [18,21-23]. The specific reasons for potentially increased susceptibility to VVN anaphylaxis after sensitization via different Hymenoptera species are not known.

Most of the anaphylactic reactions to VVN were moderate to severe. The proportion of cases with moderate-to-severe reactions was similar to that of reactions to Vespula species and A mellifera in the present series. Our data cannot answer the question of potentially more frequent anaphylaxis after VVN sting than after sting by other Hymenoptera species. Taking into account the size of VVN, a more severe reaction could be expected, as occurs with $V$ crabro sting, which is known to induce 3 times more life-threatening reactions than Vespula species or A mellifera stings [22]. Of note, 5 deaths after a VVN sting were reported during 2017 and 2018 in the Galicia region of Spain, which is home to some 2.7 million people. Thus, the number of deaths attributable to VVN was higher than expected for the general population according to a UK national database that sets the risk of death from Hymenoptera stings at 0.09 cases per million inhabitants per year $(95 \% \mathrm{CI}$, $0.07-0.10)$ [24]. These observations further support the clinical importance of emerging VVN anaphylaxis.

The lack of specific tools to diagnose and treat patients who are allergic to VVN is challenging for physicians, who must choose the best therapeutic option. In the population studied, all patients with anaphylaxis to VVN presented sIgE to Vespula species, and almost all of them presented sIgE to rVes v 5 and to $\mathrm{rPol} \mathrm{d} 5$. We also confirmed the presence of sIgE to antigen 5 from VVN by using the novel allergen $n$ Vesp v 5 in all cases from a subsample of patients with anaphylaxis to VVN. Of note, sIgE to antigen 5 from Vespula species, $P$ dominula, and VVN was closely correlated in patients with VVN anaphylaxis. Hence, antigen 5 from VVN appears to be a good candidate as a major allergen. In contrast, a poorer diagnostic value was recorded for $n$ Vesp $v 1$. In addition, sIgE to rApi $m 5$ (dipeptidyl peptidase IV, which is homologous to Ves v 3 from Vespula species) [25] was detected in more than $50 \%$ of patients with anaphylaxis to VVN; consequently, it could also be considered a major allergen. The fact that more than $70 \%$ of patients with 
anaphylaxis to VVN reacted against all the venoms used in the study suggests a high level of cross-reactivity that cannot be explained though sensitization to CCD. Therefore, further studies are needed to identify other relevant allergens in VVN venom that would likely react to other venoms as well.

Analogies in the sensitization profile of patients who experience anaphylaxis to VVN and Vespula species led us to systematically use a commercially available immunotherapy regimen based on Vespula species (data not shown). To date, only 5 patients with anaphylaxis to VVN and treated with Vespula species venom were stung by VVN after initiating immunotherapy, and none presented systemic reactions (data not shown). Likewise, immunotherapy with Vespula species in patients with anaphylaxis to $V$ orientalis has proven to be efficacious [23], and immunotherapy with Vespula species was efficacious in patients with anaphylaxis to V crabro [26]. Further studies are needed to develop specific immunotherapy for VVN, and a longer follow-up is needed to support the efficacy of immunotherapy initiated in the patients we treat. Meanwhile, commercially available Vespula-based immunotherapy seems to be a wise option in patients with VVN anaphylaxis.

Our study is subject to a series of limitations. First, the cause of anaphylaxis was classified according to the identification of the culprit insect provided by the patients, because samples of the insects were not available. Classification is always problematic when dealing with anaphylaxis due to Hymenoptera species. However, the fact that almost all patients live or work in a rural environment, where Hymenoptera are easily recognized, decreases the risk of misidentification. Besides, given that VVN has become very well-known in our region as a result of its proliferation, photographs of insects and their nests are frequently displayed in local newspapers and on television. The reason 2 patients were unable to identify the culprit insect was that they had not seen it. Second, determinations of sIgE to VVN venom and nVesp v 5 were available for a small subsample of patients; therefore, findings should be confirmed in larger studies. Finally, as already mentioned, further molecular and follow-up studies are needed to add information to the profile and outcome of patients that cannot be provided from this preliminary, cross-sectional study.

In conclusion, anaphylaxis to VVN is a relevant, emerging problem and has quickly become the most common type of Hymenoptera anaphylaxis in our area. Similarities in sensitization profile between VVN and other Vespidae (particularly Vespula species) could help in the diagnosis and treatment of VVN anaphylaxis when specific determinations and immunotherapy are not readily available.

\section{Acknowledgments}

The authors thank Emilia Martínez Lourido for helping with the collection and storage of serum samples

\section{Funding}

The study was supported by the Instituto de Salud Carlos III (Fondo de Investigaciones Sanitarias, Spanish Ministry of Health, PI16/1401 and PI19/01023) and Fundación de la Sociedad Española de Alergología e Immunología Clínica (SEAIC).

\section{Conflicts of Interest}

Carmen Vidal reports grants from Fundación SEAIC and grants from Instituto Carlos III during the conduct of the study.

Rafael Monsalve is an employee of ALK-Abelló.

Agustín Galán is an employee of ALK-Abelló.

The remaining authors declare that they have no conflicts of interest.

\section{References}

1. Perrard A, Arca M, Rome Q, Muller F, Tan J, Bista S, et al. Geographic variation of melanisation patterns in a hornet species: genetic differences, climatic pressures or aposematic constraints? PLoS ONE. 2014;9:e94162.

2. Haxaire J, Bouguet JP, Tamisier JP. Vespa velutina Lepeletier, 1836, une redoutable nouveauté pour la faune de France (Hymenoptera: Vespidae). Bull Soc Entomol Fr. 2006;111:194.

3. Monceau K, Bonnard O, Thiéry D. Vespa velutina: a new invasive predator of honeybees in Europe. Journal of Pest Science. 2014:87;1-16.

4. Arca M, Mougel F, Guillemaud T, Dupas S, Rome Q, Perrard $A$, et al. Reconstructing the invasion and the demographic history of the yellow-legged hornet, Vespa velutina, in Europe. Biological Invasions. 2015:17;2357-71.

5. Villemant C, Haxaire J, Streito JC. Premier bilan de l'invasion de Vespa velutina Lepeletier en France (Hymenoptera, Vespidae). Bull Soc Entomol Fr. 2006;111:535-8.

6. Rome Q, Muller F, Gargominy O, Villemant C. Bilan 2008 de l'invasion de Vespa velutina Lepeletier en France (Hymenoptera: Vespidae). Bull Soc Entomol Fr. 2009;114:297302.

7. Villemant C, Barbet-Massin M, Perrard A, Muller F, Gargominy $\mathrm{O}$, Jiguet $\mathrm{F}$, et al. Predicting the invasion risk by the alien beehawking yellow-legged hornet Vespa velutina nigrithorax across Europe and other continents with niche models. Biological Conservation. 2011;144:2142-50.

8. Castro L, Pagola-Carte S. Vespa velutina Lepeletier, 1836 (Hymenoptera: Vespidae), recolectada en la Península Ibérica. Heteropterus Rev Entomol. 2010;10:193-6.

9. Monceau K, Thiery D. Vespa velutina nest distribution at a local scale: an 8-year survey of the invasive honeybee predator. Insect Science. 2016;00:1-12.

10. Budge GE, Hodgetts J, Jones EP, Ostoja-Starzewski JC, Hall J, Tomkies V, et al. The invasion, provenance and diversity of Vespa velutina Lepeletier (Hymenoptera: Vespidae) in Great Britain. PLOS ONE. 2017;12:e0185172.

11. Liu Z, Chen S, Zhou Y, Xie C, Zhu B, Zhu H, et al. Deciphering the venomic transcriptome of killer-wasp Vespa velutina. Sci Rep. 2015;5:9454.

12. Xie C, Xu S, Ding F, Xie M, Lv J, Yao J, et al. Clinical features of severe wasp sting patients with dominantly toxic reaction: analysis of 1091 cases. PLoS One. 2013;8:e83164.

13. Chugo S, Lizaso MT, Alvarez MJ, Arroabaren E, Lizarza S, Tabar Al. Vespa velutina nigritorax: a new causative agent in anaphylaxis. J Investig Allergol Clin Immunol. 2015;25:231-2. 
14. Brown SGA. Clinical features and severity grading of anaphylaxis. J Allergy Clin Immunol. 2004;114:371-6.

15. Bilò $M B$, Pravettoni $V$, Bignardi $D$, Bonadonna $P$, Mauro $M$, Novembre E, et al. Hymenoptera Venom Allergy: Management of Children and Adults in Clinical Practice. J Invest Allergol Clin Immunol. 2019;29:180-250.

16. Vázquez-Revuelta P, González-de-Olano D. Prevalence of Clonal Mast Cell Disorders in Patients Presenting With Hymenoptera Venom Anaphylaxis Might Be Higher Than Expected. J Invest Allergol Clin Immunol. 2018;28:193-4.

17. Monsalve RI, Gutiérrez R, Hoof I, Lombardero M. Purification and molecular characterization of phospholipase, antigen 5 and hyaluronidases from the venom of the Asian hornet (Vespa velutina). PLoS One. 2020;15(1):e0225672

18. Monsalve RI, Vega A, Marques L, Miranda A, Fernandez J, Soriano $V$, et al. Component-resolved diagnosis of vespid venom-allergic individuals: phospholipases and antigen 5 s are necessary to identify Vespula or Polistes sensitization. Allergy. 2012;67:528-36.

19. Erwin EA, Custis NJ, Satinover SM, Perzanowski MS, Woodfolk JA, Crane J, et al. Quantitative measurement of IgE antibodies to purified allergens using streptavidin linked to a highcapacity solid phase. J Allergy Clin Immunol. 2005;115:102935.

20. Turbyville JC, Dunford JC, Nelson MR. Hymenoptera of Afghanistan and the central command area of operations: assessing the threat to deployed U.S. service members with insect venom hypersensitivity. Allergy Asthma Proc. 2013:34:179-84.

21. Ollert M, Blank S. Anaphylaxis to insect venom allergens: role of molecular diagnosis. Curr Allergy Asthma Rep. 2015;15:26.

22. Antonicelli L, Bilo M, Napoli G, Farabollini B, Bonifazi F. European hornet (Vespa crabro) sting: a new risk factor for life-threatening reaction in hymenoptera allergic patients? Allerg Immunol (Paris). 2003;35:199-203.
23. Goldberg A, Shefler I, Panasoff J, Paitan Y, Confino-Cohen R Immunotherapy with commercial venoms is efficacious for anaphylactic reactions to Vespa orientalis stings. Int Arch Allergy Immunol. 2013;161:174-80.

24. Turner PJ, Gowland MH, Sharma V, Lerodiakonou D, Harper N Garcez T, et al. Increase in anaphylaxis-related hospitalizations but no increase in fatalities: an analysis of United Kingdom national anaphylaxis data. 1992-2012. J Allergy Clin Immunol. 2015;135:956-63.

25. Blank S, Seismann $H$, Bockisch B, Braren I, Cifuentes L, Mclntyre $M$, et al. Identification, recombinant expression, and characterization of the $100 \mathrm{kDa}$ high molecular weight Hymenoptera venom allergens Api $\mathrm{m} 5$ and Ves v 3. J Immunol. 2010;184:5403-13.

26. Košnik $M$, Korošec $P$, Šilar $M$, Mušiè $E$, Eren R. Wasp venom is appropriate for immunotherapy of patients with allergic reaction to the European hornet sting. Croat Med J. 2002:43:25-7.

\section{Manuscript received September 6, 2019; accepted for} publication December 16, 2019.

\section{Carmen Vidal}
Allergy Department
Complejo Hospitalario Universitario de Santiago
Faculty of Medicine, University of Santiago
Rúa Ramón Baltar, s/n
15706 Santiago de Compostela, Spain
E-mail: carmen.vidal.pan@sergas.es 